\title{
INCIDENCE OF RHEUMATIC FEVER IN RELATION TO IMMUNOLOGIC REACTIVITY
}

\author{
BY
}

\author{
V. REJHOLEC \\ WITH STATISTICAL COMPUTATIONS AND FIGURES BY V. MalÝ, AND TECHNICAL ASSISTANCE \\ By M. Repič-Šlechta and E. Haller \\ Research Institute of Rheumatic Diseases, Prague \\ (Director: Professor E. Lenoch)
}

(RECEIVED FOR PUBLICATION OCTOBER 10, 1956)

Many authors have attempted to demonstrate that subjects with a past history of rheumatic fever possess an altered immunologic reactivity, different of that of normal controls (Creger, Choy, and Rantz, 1951; Miller, Kibrick, and Massell, 1953; Quinn, Seastone, and Dickie, 1953; Kuhns and McCarty, 1954), but the results of their experiments proved mostly negative or inconclusive. A convincing proof of this altered reactivity seems to have been furnished only after attention had been focused on incomplete antibody, as shown, for example, in our previously reported experiments applying single non-streptococcal immunizing impulses (Wagner and Rejholec, 1955; Padovcová, Rejholec, Suda, Malý, and Wagner, 1956).

The assumption of increased immunologic reactivity appearing thus corroborated, the next problem we faced was whether this particular hyperreactivity was primary or secondary in character. In the latter case it would be a sequela of the past rheumatic disease; in the former, viz. if it had been present in the subject before the onset of rheumatic fever, it might be inferred that it had a bearing on the pathogenic mechanism of this disease.

In order to elucidate this question we adopted the following procedure. The immunologic reactivity of a group of young healthy subjects as homogeneous as possible, was tested, and during the nine following months they were observed for incidence of rheumatic fever and the occurrence of sore throats. The observed morbidity was compared with the immunologic reactivity determined at the outset. In patients with sore throats the erythrocyte sedimentation rate was also measured and related with the results of the immunologic tests.

\section{Method}

(1) Determination of Reactivity.-Immunization was performed by a single subcutaneous injection of the Brucella abortus bacterine of No. 3 density, measured by the densimetric scale of McFarland (1907), i.e. about 200 million bacteria in $1 \mathrm{ml}$. On the 14th day after the injection blood samples were taken from the cubital vein and the sera were assessed for the titres of agglutinins and incomplete antibody. The method of this examination had been described previously (Wagner and Rejholec, 1955), the only difference was that in the present experiments the scale of dilutions started at 1:20 instead of at $1: 4$. All sera were tested up to the final titres which never exceeded 1:40 for agglutinins or 1:2,560 for incomplete antibody.

(2) Selection of Subjects.-Immunization was performed on members of the lowest classes of a trainingschool for mining and related crafts, where all the apprentices were lodged in a hostel. All the boys first underwent a thorough medical examination, and all boys with a history of rheumatic fever or clinical signs of possible rheumatic origin, were excluded. The rest made up a total of 998 boys of between 15 and 16 years of age.

(3) Scope of Observation of Immunized Subjects. - The hostel is equipped with a hospital of its own with a dispensary and wards for less severe cases of illness. All boys who fall ill have to report at the dispensary. In the course of our experiments, if one of the immunized subjects was found to have a sore throat (tonsillitispharyngitis) the erythrocyte sedimentation rate was immediately determined, and was then measured every third day until it became normal and the illness had disappeared. All this was done regardless of the mode of therapy, which was mostly antibiotic. Bacteriological cultures were grown only at random. Whenever rheumatic fever was diagnosed, the patient was registered at the dispensary and immediately transported to the district hospital. 


\section{Results}

Fig. 1, upper part, illustrates the percentage distri-

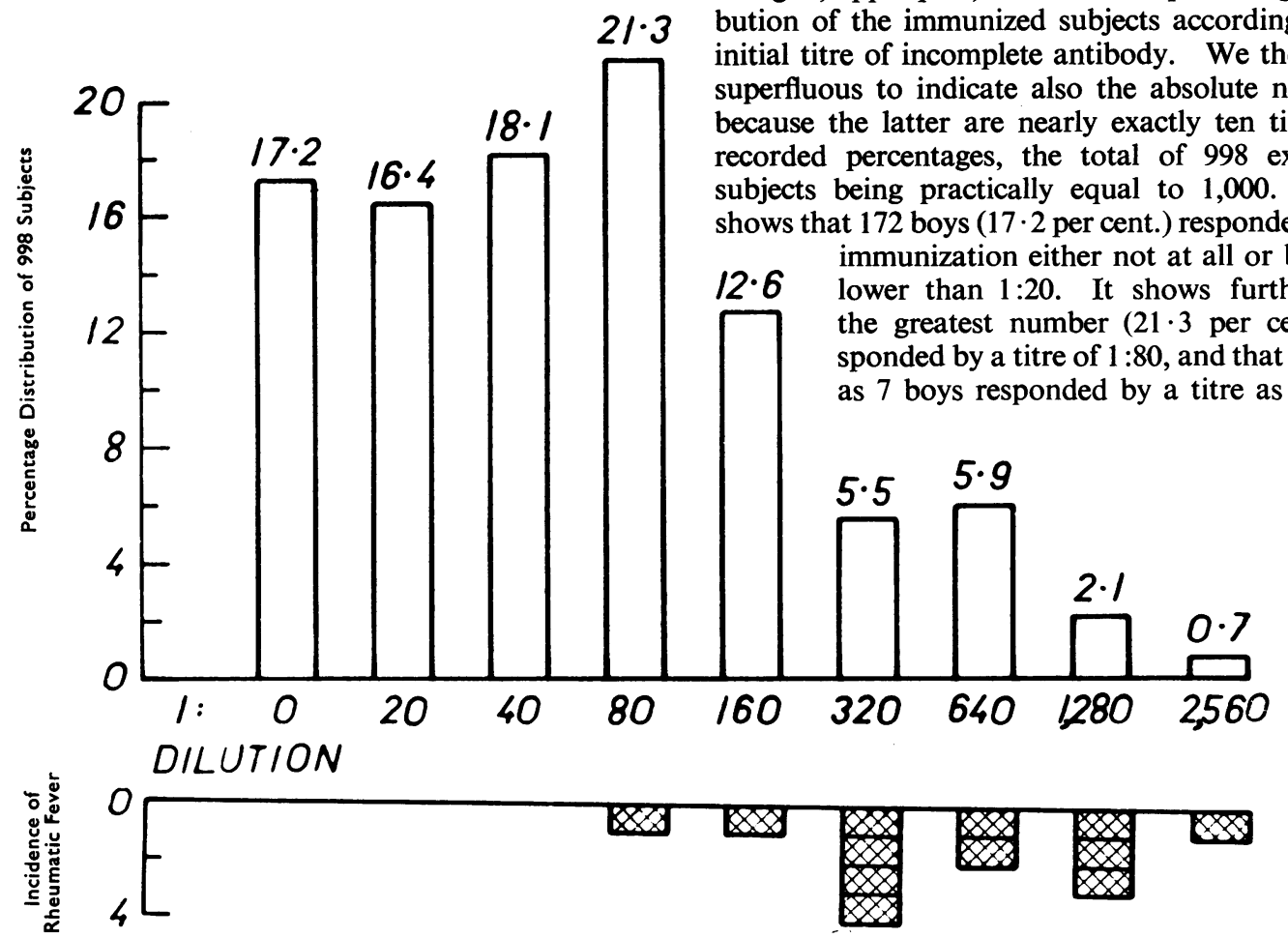

Fig. 1.-Percentage distribution of 998 observed subjects according to the initial titre of immunological reactivity (SeptemberOctober, 1955).

Actual incidence of rheumatic fever in observation period (September-October, 1955-June, 1956) plotted against individual initial titres.

The upper and the lower columns are not on the same scale. They would only be so if the upper columns were raised ten times and thus became absolute numbers instead of percentages.

The immunization was performed in the 2 weeks after the school opening (September, 1955) and the observation period lasted for 9 months till the end of the summer term (June, 1956).

(4) Evaluation of Results. - Three basic values were computed:

(i) Incidence of sore throat.

(ii) Average of the highest erythrocyte sedimentation rate values after 1 hour and 2 hours reached by each subject who fell ill with sore throat.

(iii) Incidence of rheumatic fever.

The results were correlated, mostly by the $\chi^{2}$ method with the results of the serologic test for incomplete antibody, i.e. with the immunologic reactivity which has been determined at the outset. In the course of this communication "initial reactivity" means the titre of response by incomplete antibody. Several of the values under observation were also computed separately for the first 4 and last 5 months of observation.
$1: 2,560$. At the $1: 640$ level a sudden rise in the rate disturbs the otherwise rather smooth curve in a manner which seems to suggest a second peak. It is clear that, if titres of 1:10 and 1:5 had also been investigated, the column of negative results would have come out much lower, so that the rising curve would be smoother and the whole curve more symmetrical.

As only 29 boys responded by production of agglutinins, and that only up to the titre of $1: 40$, no $N$ statistical evaluation of this characteristic in relation to other elements was possible, and the distribution of titres of complete antibody has not been charted owing to paucity of numbers.

Table I (opposite) records the incidence of sore throats according to month and to the initial titre levels. The whole incidence in the 9 months of observation comprised 212 cases. The nineteen boys who fell ill with sore throat more than once were 
TABLE I

INCIDENCE OF SORE THROAT AND RHEUMATIC FEVER CASES DISTRIBUTED ACCORDING TO MONTHS AND TO INITIAL TITRES

\begin{tabular}{|c|c|c|c|c|c|c|c|c|c|c|}
\hline \multirow{2}{*}{ Titre } & \multicolumn{9}{|c|}{ Months since Immunization } & \multirow{2}{*}{ Total } \\
\hline & $\begin{array}{c}1 \\
\text { (Oct.) }\end{array}$ & $\stackrel{2}{\text { (Nov.) }}$ & $\begin{array}{c}3 \\
\text { (Dec.) }\end{array}$ & $\begin{array}{c}4 \\
\text { (Jan.) }\end{array}$ & $\begin{array}{c}5 \\
\text { (Feb.) }\end{array}$ & $\begin{array}{c}6 \\
\text { (Mar.) }\end{array}$ & $\begin{array}{c}7 \\
\text { (Apr.) }\end{array}$ & $\stackrel{8}{(\text { May) }}$ & $\begin{array}{c}9 \\
\text { (June) }\end{array}$ & \\
\hline 0 & 3 & 11 & 2 & 3 & 6 & 3 & 7 & 0 & 1 & 36 \\
\hline 20 & 6 & 14 & 1 & 0 & 3 & 2 & 4 & 1 & 0 & 31 \\
\hline 40 & 12 & 9 & 6 & 2 & 4 & 0 & 4 & 2 & 4 & 43 \\
\hline 80 & 2 & 15 & 9 & 4 & 0 & 0 & 5 & $3(1)$ & 3 & $41(1)$ \\
\hline 160 & 0 & 12 & 2 & 0 & $5(1)$ & 0 & 2 & 1 & 0 & $22(1)$ \\
\hline 320 & 1 & 5 & $2(1)$ & $3(1)$ & 0 & 1 & $3(2)$ & 2 & 0 & $17(4)$ \\
\hline 640 & 0 & $6(1)$ & 4 & 1(1) & 2 & 0 & 1 & 1 & 0 & $15(2)$ \\
\hline $\begin{array}{l}1,280 \\
\text { and above }\end{array}$ & 0 & $2(2)$ & $2(2)$ & 0 & 0 & 1 & 0 & 2 & 0 & $7(4)$ \\
\hline Total & 42 & $74(3)$ & $28(3)$ & $13(2)$ & $20(1)$ & 7 & $26(2)$ & $12(1)$ & 8 & $212(12)$ \\
\hline
\end{tabular}

No. of rheumatic fever cases in brackets. ( )

recorded each time as independent cases. Table I shows that the highest incidence occurred in November (the second month of observation) and that a second wave appeared in April (the seventh month).

Table II shows the total cases of sore throat for the first 4 months of observation (Oct.-Jan., Cols 3 and 4), for the remaining 5 months (Feb.-June, Cols 5 and 6), and for the whole period (Cols 7 and 8), distributed according to the initial titre levels (Col. 1). Col. 2 indicates the distribution of titres in absolute numbers, and the percentages (Cols 4,6 , and 8 ) are computed from the numbers of subjects in each grade.

In order to evaluate the results statistically we reasoned as follows:

In the first 4 months, 139 boys ( $13 \cdot 8$ per cent.) fell ill with sore throat. If the frequency of sore throats were not dependent on the titre level, we should be entitled to expect about the same frequency of sore throats to appear in every subgroup. In fact, the observed percentages in these subgroups ranged from 11 per cent. for negative titres to 20 per cent. for the titre of $1: 320$. Similarly, $7 \cdot 3$ per cent. was the expected frequency for the remaining 5 months in every subgroup, but the observed frequencies ranged from $5 \cdot 1$ per cent. in the titre of $1: 80$ to 10.9 per cent. in the titre of $1: 320$. The expected frequency in the whole observation period was $21 \cdot 2$ per cent., but the observed frequencies were scattered from 17.4 per cent. in the titre of $1: 160$ to 30.9 per cent. in the titre of $1: 320$.

We subjected all the expected frequencies to comparison with all those observed in the respective periods by the $\chi^{2}$ test (Fisher, 1936), and found that none of the three $\chi^{2}$ values was statistically significant. Consequently, we are bound to regard the deviations of the observed from the expected frequencies as due to chance. Thus, we were not able to show that the incidence of sore throats depended on the titre of reactivity.

TABLE II

CORRELATION OF INITIAL TITRE WITH THE OCCURRENCE OF SORE THROATS IN THE FIRST FOUR MONTHS, THE REMAINING FIVE MONTHS, AND THE WHOLE PERIOD OF OBSERVATION

\begin{tabular}{|c|c|c|c|c|c|c|c|}
\hline \multirow{3}{*}{ Initial Titre } & \multirow{3}{*}{$\begin{array}{l}\text { Number of } \\
\text { Subjects } \\
\text { with this } \\
\text { Titre }\end{array}$} & \multicolumn{6}{|c|}{ Cases of Sore Throat } \\
\hline & & \multicolumn{2}{|c|}{ First 4 Months } & \multicolumn{2}{|c|}{ Remaining 5 Months } & \multicolumn{2}{|c|}{ Whole Observation Period } \\
\hline & & Number & Per cent. & Number & Per cent. & Number & Per cent. \\
\hline 1 & 2 & 3 & 4 & 5 & 6 & 7 & 8 \\
\hline $\begin{array}{r}0 \\
20 \\
40 \\
80 \\
160 \\
320 \\
640 \\
1,280 \text { and above }\end{array}$ & $\begin{array}{l}172 \\
164 \\
181 \\
213 \\
126 \\
55 \\
59 \\
28\end{array}$ & $\begin{array}{r}19 \\
21 \\
29 \\
30 \\
14 \\
11 \\
11 \\
4\end{array}$ & $\begin{array}{l}11 \cdot 0 \\
12 \cdot 8 \\
16 \cdot 0 \\
14 \cdot 1 \\
11 \cdot 1 \\
20 \cdot 0 \\
18 \cdot 6 \\
14 \cdot 3\end{array}$ & $\begin{array}{r}17 \\
10 \\
14 \\
11 \\
8 \\
6 \\
4 \\
3\end{array}$ & $\begin{array}{r}9 \cdot 8 \\
6 \cdot 0 \\
7 \cdot 7 \\
5 \cdot 1 \\
6 \cdot 3 \\
10 \cdot 9 \\
6 \cdot 7 \\
10 \cdot 7\end{array}$ & $\begin{array}{r}36 \\
31 \\
43 \\
41 \\
22 \\
17 \\
15 \\
7\end{array}$ & $\begin{array}{l}20 \cdot 9 \\
18 \cdot 8 \\
23 \cdot 7 \\
18 \cdot 2 \\
17 \cdot 4 \\
30 \cdot 9 \\
25 \cdot 4 \\
25 \cdot 0\end{array}$ \\
\hline Totals & 998 & 139 & $13 \cdot 8$ & 73 & $7 \cdot 3$ & 212 & $21 \cdot 2$ \\
\hline
\end{tabular}


TABLE III

MEAN ERYTHROCYTE SEDIMENTATION RATES AT 1 HOUR AND AT 2 HOURS OF SUBJECTS ILL WITH SORE THROAT RELATED TO INITIAL TITRE

\begin{tabular}{|c|c|c|c|c|c|c|c|c|c|}
\hline \multirow{3}{*}{ Titre } & \multicolumn{3}{|c|}{ First 4 Months } & \multicolumn{3}{|c|}{ Remaining 5 Months } & \multicolumn{3}{|c|}{ Whole Observation Period } \\
\hline & \multirow{2}{*}{$\begin{array}{l}\text { No. of } \\
\text { Cases }\end{array}$} & \multicolumn{2}{|c|}{ Mean ESR (mm.) } & \multirow{2}{*}{$\begin{array}{l}\text { No. of } \\
\text { Cases }\end{array}$} & \multicolumn{2}{|c|}{ Mean ESR (mm.) } & \multirow{2}{*}{$\begin{array}{l}\text { No. of } \\
\text { Cases }\end{array}$} & \multicolumn{2}{|c|}{ Mean ESR (mm.) } \\
\hline & & $1 \mathrm{hr}$ & $2 \mathrm{hrs}$ & & $1 \mathrm{hr}$ & $2 \mathrm{hrs}$ & & $1 \mathrm{hr}$ & 2 hrs \\
\hline $\begin{array}{r}0 \\
20 \\
40 \\
80 \\
160 \\
320 \\
640 \\
1,280 \\
\text { and above }\end{array}$ & $\begin{array}{r}19 \\
21 \\
29 \\
30 \\
14 \\
11 \\
11 \\
4\end{array}$ & $\begin{array}{l}13 \cdot 2 \\
16 \cdot 1 \\
15 \cdot 1 \\
28 \cdot 6 \\
31 \cdot 1 \\
34 \cdot 9 \\
31 \cdot 6 \\
28 \cdot 9\end{array}$ & $\begin{array}{l}21 \cdot 0 \\
21 \cdot 9 \\
23 \cdot 6 \\
45 \cdot 1 \\
69 \cdot 9 \\
72 \cdot 3 \\
66 \cdot 7 \\
54 \cdot 0\end{array}$ & $\begin{array}{r}17 \\
10 \\
14 \\
11 \\
8 \\
6 \\
4 \\
3\end{array}$ & $\begin{array}{l}16 \cdot 0 \\
20 \cdot 5 \\
17 \cdot 3 \\
23.0 \\
26 \cdot 5 \\
21 \cdot 5 \\
18 \cdot 6 \\
15 \cdot 7\end{array}$ & $\begin{array}{l}25 \cdot 6 \\
25 \cdot 9 \\
29 \cdot 8 \\
32 \cdot 3 \\
48 \cdot 5 \\
53 \cdot 5 \\
49 \cdot 5 \\
38 \cdot 0\end{array}$ & $\begin{array}{r}36 \\
31 \\
43 \\
41 \\
22 \\
17 \\
15 \\
7\end{array}$ & $\begin{array}{l}14 \cdot 6 \\
18 \cdot 3 \\
16 \cdot 2 \\
25 \cdot 8 \\
28 \cdot 8 \\
28 \cdot 2 \\
25 \cdot 1 \\
22 \cdot 3\end{array}$ & $\begin{array}{l}23 \cdot 3 \\
23 \cdot 9 \\
26 \cdot 7 \\
38 \cdot 7 \\
59 \cdot 2 \\
62 \cdot 9 \\
58 \cdot 1 \\
46 \cdot 0\end{array}$ \\
\hline Total & 139 & & & 73 & & & 212 & & \\
\hline
\end{tabular}

The means were calculated from the sedimentation rate peaks of subjects falling ill with sore throat in each period and belonging to the same titre.

Table III gives the average erythrocyte sedimentation rates in 1 hour and in 2 hours in those who fell ill with sore throat in the first 4 months, the remaining 5 months, and the whole period. They are grouped according to the initial titres of incomplete antibody. The Table shows that subjects who had responded to the immunization by higher titres presented also on the average a substantially higher erythrocyte sedimentation rate than the rest when they fell ill with sore throat. Thus nineteen boys who fell ill in the first 4 months and who had responded negatively showed an average erythrocyte sedimentation rate of $13.2 \mathrm{~mm} . / 1 \mathrm{hr}$ and $21.0 \mathrm{~mm}$. $/ 2 \mathrm{hrs}$, while for the eleven boys who had responded by a titre of $1: 320$ the rates were 34.9 and $72.3 \mathrm{~mm}$. It is worth noting that in the last 5 months the differences are not nearly so clear cut, though they remain discernible. The average for the whole observation period stands roughly in the middle. The correlation of mean erythrocyte sedimentation rate and immunologic reactivity is much more distinct for the erythrocyte sedimentation rate in 2 hours than that in 1 hour. E.g. the rate of subjects with the titre of $1: 320$ is considerably more than three times that of those with a titre of 0 , if one considers the rates at 2 hours $(21 \cdot 0: 72 \cdot 3)$, but less than three times higher for the rates at 1 hour $(13 \cdot 2: 34 \cdot 9)$. A slight drop of values in the highest titres is due perhaps to paucity of numbers.

Several of the data recorded in Table III are illustrated in Fig. 2 (opposite), which charts the general rise in average sedimentation rates in $1 \mathrm{hr}$ and $2 \mathrm{hrs}$ accompanying the rise in titres.

The fact that this correlation seems to become less marked in the highest titres is dealt with in the Discussion. Fig. 2 shows that this parallelism is more marked in the first 4 months of observation (white columns) than in the last 5 months (black columns); the latter show a certain flattening of the curve; the black columns are higher for all lower titres and lower for all higher titres, especially in the values for 1 hour. The height of the black column in 1 hour for negative reactors is almost the same as for the highest reactors; in 2 hours, however, even the black columns are well differentiated and markedly higher for higher titres.

In the course of the 9 months' strict observation, twelve $(1 \cdot 2$ per cent.) fell ill with rheumatic fever. The diagnosis was made by the accepted criteria, and in all twelve cases it was possible to ascertain the preliminary infectious component (tonsillar inflammation). For this reason, the rheumatic fever cases are also recorded in Table I where they are given in brackets. The distribution of patients according to the initial titre of incomplete antibody is illustrated in the lower part of Fig. 1. One patient had shown the titre of $1: 80$, one of $1: 160$, four of $1: 320$, and one of 1:2,560. All those who fell ill with rheumatic fever in the 9 months following this immunological grading were good producers of incomplete antibody.

In order to ascertain the statistical significance of the relationship between the initial titre of incomplete antibody and the incidence of rheumatic fever, we subjected our results to appropriate evaluations. The subjects were divided into those who had responded immunologically up to three selected titre levels and those whose response was above these levels. The chosen levels were $1: 40,1: 80$, and 1:160. The results are shown in Table IV (opposite).

Of 51.8 per cent. who responded up to the titre of $1: 40$, not one fell ill with rheumatic fever. It follows, according to the statistical tables of Mainland (1948), with the probability of 0.99 (i.e. almost with certainty) that the probability that a subject conforming to our sample of 998 will fall ill with rheumatic fever in the next 9 months, is less than $1 \cdot 1$ per cent. if he shows a titre of not more than 1:40; if his titre is above this level, the probability lies between 0.99 and 4.8 per cent.

With titres up to or above $1: 80$ the probability is less than 1.5 per cent. and between 1.7 and 8.9 per cent. respectively.

With titres up to or above $1: 160$, it is less than 1.5 per cent. and between $2 \cdot 7$ and $14 \cdot 7$ per cent. respectively.

We also examined the relationship between the incidence of rheumatic fever and the reactivity grade by 

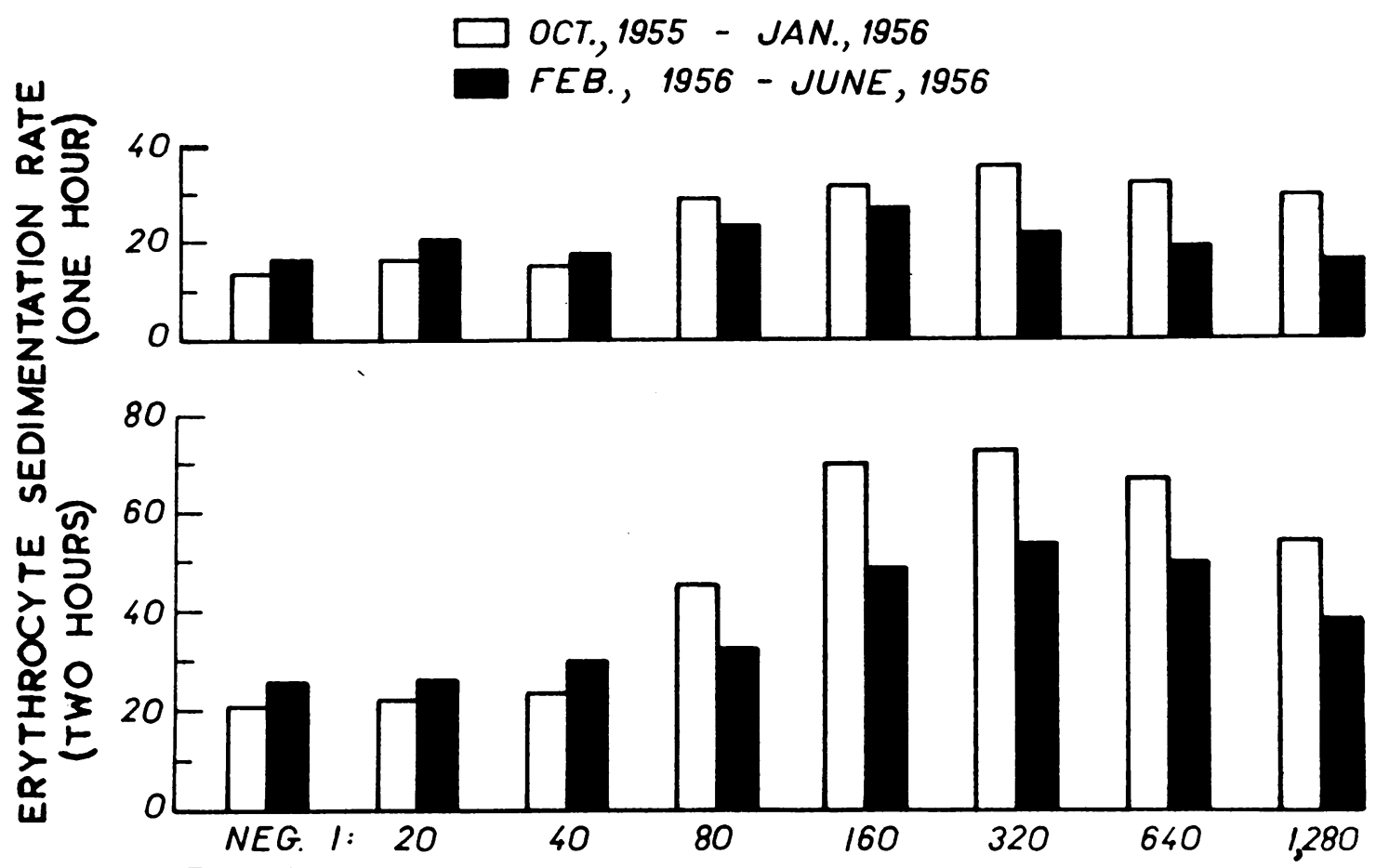

TITRE

Fig. 2.-Mean erythrocyte sedimentation rate in 1 hour and 2 hours of subjects ill with sore throat.

Means calculated from peaks of individual erythrocyte sedimentation rate in 1 hour (upper histogram) and 2 hours (lower histogram) of subjects ill with sore throat, showing initial reactivity titre. White columns refer to the first $\mathbf{4}$ months of observation and black columns to the ast 5 months.

means of the $\chi^{2}$ test (Table IV). In all three chosen instances, the value of $\chi^{2}$, determined by the table of Fisher (1936), proved statistically significant at the 1 per cent. level. It follows that the probability that the occurrence of rheumatic fever is independent of the titre is less than 1 per cent., and that the probability of an association between morbidity and degree of reactivity is extremely high.

TABLE IV

CORRELATION BETWEEN THE INITIAL TITRE OF INCOMPLETE ANTIBODY AND INCIDENCE OF RHEUMATIC FEVER, BY $\chi^{2}$ TEST: $(a)$ TITRES UP TO OR ABOVE $1: 40$; (b) TITRES UP TO OR ABOVE $1: 80 ;$ (c) TITRES UP TO OR ABOVE $1: 160$

\begin{tabular}{|c|c|c|c|c|c|}
\hline & \multirow{2}{*}{ Titre } & \multirow{2}{*}{ Number } & \multicolumn{2}{|c|}{$\begin{array}{c}\text { Incidence of } \\
\text { Rheumatic Fever }\end{array}$} & \multirow{2}{*}{$\chi^{2}$} \\
\hline & & & Observed & Expected & \\
\hline \multirow{2}{*}{ (a) } & up to $1: 40$ & 517 & 0 & $6 \cdot 2$ & \multirow{2}{*}{$12 \cdot 827$} \\
\hline & above $1: 40$ & 481 & 12 & $5 \cdot 8$ & \\
\hline \multirow{2}{*}{ (b) } & up to $1: 80$ & 730 & 1 & $8 \cdot 8$ & \multirow{2}{*}{$25 \cdot 926$} \\
\hline & above $1: 80$ & 268 & 11 & $3 \cdot 2$ & \\
\hline \multirow{3}{*}{ (c) } & up to $1: 160$ & 856 & 2 & $10 \cdot 1$ & \multirow{2}{*}{$41 \cdot 027$} \\
\hline & above $1: 160$ & 142 & 10 & 1.9 & \\
\hline & Total & 998 & 12 & 12 & \\
\hline
\end{tabular}

The time sequence in which single subjects fell ill with rheumatic fever is recorded in Table V. In the second month (November, 1955), three cases of rheumatic fever were diagnosed, that with the lowest antibody concentration having had a titre of $1: 640$, and the titres of the other two being higher by one and two dilutions respectively. In the following month three further cases occurred, two with an initial titre of $1: 1,280$ and one with only $1: 320$. In the fifth month one single case had an initial titre of

$$
\text { TABLE V }
$$

OCCURRENCE OF RHEUMATIC FEVER IN MONTHS FOLLOWING IMMUNIZATION RELATED TO THE INITIAL TITRE OF INCOMPLETE ANTIBODY

\begin{tabular}{r|r|r|r|r|r|r|r|r|r|r}
\hline \multirow{2}{*}{ Titre } & \multicolumn{1}{|c|}{ Month } & & \\
& 1 & 2 & 3 & 4 & 5 & 6 & 7 & 8 & 9 & Total \\
\hline 80 & & & & & & & & 1 & & 1 \\
160 & & & & & 1 & & & & & 1 \\
320 & & & 1 & 1 & & & 2 & & & 4 \\
640 & & 1 & 2 & 1 & & & & & & 3 \\
1,280 & & 1 & 2 & & & & & & & 1 \\
2,560 & & 1 & & & & & & & & 1 \\
\hline Totals & 0 & 3 & 3 & 2 & 1 & 0 & 2 & 1 & 0 & 12 \\
\hline
\end{tabular}

In titres lower than 1:80 no rheumatic fever occurred.

In the months immediately following the immunologic grading, the subjects with higher titres were prone to fall ill sooner, while with the lapse of time subjects with moderate initial titres became liable to contract the disease. 
$1: 160$, in the seventh month two cases had an initial titre of $1: 320$, and finally in the eighth month the last case had an initial titre of $1: 80$. Thus it seems that the longer the time since the immunologic grading, the more likely is it that a subject whose reactivity was originally low will fall ill, and vice versa.

Table VI indicates the average titres of incomplete antibody of subjects who fell ill with rheumatic fever in each month.

TABLE VI

MEAN TITRES OF INCOMPLETE ANTIBODY IN OBSERVED CASES OF RHEUMATIC FEVER, DISTRIBUTED ACCORDING TO MONTH OF OCCURRENCE

\begin{tabular}{c|c|c|c}
\hline $\begin{array}{c}\text { Months since } \\
\text { Immunization }\end{array}$ & $\begin{array}{c}\text { Number } \\
\text { of Cases }\end{array}$ & $\begin{array}{c}\text { Initial Titre } \\
\text { of Individual Patients }\end{array}$ & $\begin{array}{c}\text { Average } \\
\text { Titres }\end{array}$ \\
\hline 1 & 0 & - & - \\
\hline 2 & 3 & 2,$560 ; 1,280 ; 640$ & 1,280 \\
\hline 3 & 3 & 1,$280 ; 1,280 ; 320$ & 806 \\
\hline 4 & 2 & $640 ; 320$ & 453 \\
\hline 5 & 1 & 160 & 160 \\
\hline 6 & 0 & - & - \\
\hline 7 & 2 & $320 ; 320$ & 320 \\
\hline 8 & 1 & 80 & 80 \\
\hline 9 & 0 & - & - \\
\hline
\end{tabular}

The mean titres (computed as geometric means) gradually decline. The mean titres seem rather suggestive, though their reliability is slight owing to paucity of numbers.

\section{Discussion}

The discrepancy between cases of streptococcal infection and the actual incidence of rheumatic fever as the sterile post-streptococcal state (Rantz, Spink, and Boisvert, 1946) suggests that the pathogenesis of rheumatic fever has apparently an individual predisposition of some sort among its components. A number of authors have already suggested that this predisposition might consist in a certain exceptional reactivity or hypersensitivity of the affected subjects (Evans, 1947). This condition has up to now been sought in the field of immunology and demonstrated with more or less success (Creger, Choy, and Rantz, 1951; Miller, Kibrick, and Massell, 1953; Quinn, Seastone, and Dickie, 1953; Kuhns and McCarty, 1954; Aikawa, 1954). The clear-cut results of our previous research concerning the presence of incomplete antibody in subjects with a past history of rheumatism (Wagner and Rejholec, 1955; Padovcová, Rejholec, Suda, Malý, and Wagner, 1956) seem to suggest that the methods developed for detecting incomplete antibody produced by an impulse other than streptococcal impulse offer an appropriate procedure for determining this reactivity.

The results of the present research contribute several interesting observations to the previous one with which it is closely linked. In our sample of 998 boys, which was exceptionally homogeneous as to age, lodging, board, occupation, climate, etc., we were able to detect important differences in the immunologic reactivity of individuals, as far as this reactivity was measured by the response with incomplete antibody to the Brucella antigen. Besides those who did not respond at all to the standard antigenic stimulus, we found rather a high proportion who reacted with antibody concentrations as high as those of subjects with a past history of rheumatism, as reported in our previous communication, and this although all persons with rheumatic fever or even a suspicion of rheumatism in their past history were rigorously excluded.

Our aim was to discover whether these "immunologic hyper-reactors" are not in fact potential rheumatics. We also investigated the relation between immunologic reactivity and the incidence of sore throat. Bacteriological tests were not carried out in every single case, but most of these illnesses were clearly, by their clinical characteristics, of $\mathscr{C}$ streptococcal aetiology. However, no correlatio was found which could be evaluated statisticallys The probability of a hyper-reactor falling ill wits sore throat is about the same as that of a non-reactor. Likewise, in the clinical course of the illness, no difference could be discerned, either in the gravity of symptoms or the effectiveness of therapy, though the average hospitalization of the hyper-reactors was longer by several days, since their raised sedimentation rates imposed a greater degree of caution upon the physician. In the course of our experiments we began to extend the hospitalization of hyper-reactors on yet another ground: we found that they were manifestly more exposed to the danger of rheumatic fever as a sequela of sore throat. We cannot, however, assert that this precaution actually prevented any case of rheumatic fever which would otherwise have developed.

The systematic follow-up of erythrocyte sedimentation rate has demonstrated a close correlation between these findings and immunologic reactivity.

Immunologic reactivity is manifestly not an unalterable condition and may change as time goes on. The same may be said of the relationship between the incidence of rheumatic fever and immunologic $\varrho$ reactivity. We are endeavouring to elucidate this time factor in another communication, now in preparation, which seems to show that reactivity may change within relatively broad limits and that the

\section{(1)} $\underset{0 .}{0}$ $\overrightarrow{\overline{\vec{F}}}$ ,

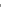

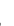

(n)

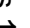
然 W

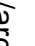
क (n)

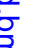
.

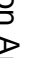
? 产

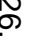
苋 W

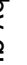

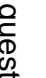

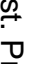

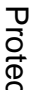


grade of reactivity may be influenced by such conditions as nutrition, occupation, and mental strain (Rejholec, Hrubcová, Malý, and Wagner). The existence of the top grades of reactivity may be assumed to be of short duration; the relatively rapid decline of this exaggerated reactivity may account for certain irregularities in the curves, e.g. for the fact that the mean erythrocyte sedimentation rate in the titres $1: 640$ and $1: 1,280$ were lower than those in the titre $1: 320$. The time factor observed in those instances where we have divided our observations into two stages (the first 4 and the remaining 5 months of observation) appears to have made its influence felt pre-eminently in these top grades of reactivity.

The statistically established close association of titre with incidence of rheumatic fever suggests that reactivity may in fact be the predisposing element responsible for the discrepancy between the "possible" cases (i.e. those who had suffered the impact of the external noxa, the haemolytic streptococcal infection) and the "actual" cases (i.e. those who fell ill with rheumatic fever) which can be viewed as a post-streptococcal sequela (Rantz, Spink, and Boisvert, 1946). The reactivity thus appears to be the primary factor directly associated with the pathogenesis, whether we approach it from the immunological angle or from a broader viewpoint.

The statistical evaluations (see Results) must be taken, of course, with due statistical reservations. Generalizing from the experience gained by observing samples is an especially delicate operation. In the present instance the examined sample was a highly selected one, but its large size diminishes substantially the role of chance in the results. Moreover, the mode of selection tended to exclude subjects possessing characteristics whose relation to the onset of rheumatic fever is already established, so that the assumed play of reactivity might proceed unhampered. The probabilities derived from our observations cannot be applied to both sexes, to all stages of life, or to persons living in any other environmental conditions, but our results show how future trials, undertaken with samples unselected or selected on other bases, may answer the question of the relationship of immunologic reactivity and incidence of rheumatic fever.

Our experiments suggest the possibility of finding out, by means of immunologic grading, "potential rheumatics" among the population, and of directing upon them an intensified preventive effort. The variability of individual reactivity represents a distinct impediment to such a policy, as it would impose on the public health worker the task of re-grading all followed-up subjects at least once a year, and such an undertaking would scarcely be compatible with the facilities at the disposal of existing public health institutions.

\section{Summary}

A homogeneous group of 998 subjects without signs of rheumatism were immunized by a single injection of Brucella bacterine and the titre of incomplete antibody was determined in each subject. The incidence of sore throats and rheumatic fever was observed during a period of 9 months, the erythrocyte sedimentation rate being determined during each affection of the upper respiratory tract. The incidence of sore throat did not in the least depend on the grade of immunologic reactivity, but the correlation of the latter with the incidence of rheumatic fever was found to be highly significant. All the twelve subjects who fell ill with rheumatic fever during the observation period were good producers of incomplete antibody, most of them being extremely good producers. With the passage of time, however, the reactivity titre in certain individuals appeared to change and the distinctness of the results became less marked. We also found further that subjects with high titres had a substantially higher erythrocyte sedimentation rate when they fell ill with sore throat than those with low titres. The difference was more conspicuous for the E.S.R. values after 2 hours than those after 1 hour. Here also the correlation was more definite soon after the immunologic grading of the subject than at a later period. Several questions concerning the relationship between immunologic reactivity and the pathogenesis of rheumatic fever are discussed and the possibility of a practical application of the results obtained is considered.

The assistance given us in different stages of this study by Drs. J. Černý, J. Maleček, J. Matějů, K. Srám, V. Wagner, and others, is sincerely appreciated. We are indebted particularly to Professor F. Lenoch for valuable advice.

\section{REFERENCES}

Aikawa, J. K. (1954). Ann. intern. Med., 41, 576.

Creger, W. P., Choy, S. H., and Rantz, L. A. (1951). J. Immunol., Creger, W6, $\mathbf{4 4 5}$.

Evans, S. M. (1947). Wisconsin med. J., 46, 783.

Fisher, R. A. (1936). "Statistical Methods for Research Workers", 6 th ed. Oliver and Boyd, Edinburgh.

Kuhns, W. J., and McCarty, M. (1954). J. clin. Invest., 33, 759.

McFarland, J. (1907). J. Amer. med. Ass., 49, 1176.

Mainland, D. (1948). Canad. J. Res. (E.), 26, 1-106.

Miller, J. M., Kibrick, S., and Massell, B. F. (1953). J. clin. Invest., 32, 691 .

Padovcová, H., Rejholec, V., Suda, C., Malý, V., and Wagner, V. (1956). Ann. Paediat., 187, 351.,

Quinn, R. W., Seastone, V. C., and Dickie, H. A. (1953). J. Immunol., 70,493 .

Rantz, L. A., Spink, W. W., and Boisvert, P. J. (1946). Arch. intern. Med., 77, 66.

Rejholec, V., Hrubcová, M., Malý, V., and Wagner, V. In press.

Wagner, V., and Rejholec, V. (1955). Annals of the Rheumatic Diseases, 14, 243. 
Fréquence du rhumatisme articulaire aigu par rapport á la réactivité immunologique.

\section{RÉSUMÉ}

Un groupe homogène de 998 sujets ne présentant pas de signes de rhumatisme fut immunisé par une seule injection de vaccin bactérien Brucella et le titre d'anticorps incomplet fut déterminé pour chaque sujet. La fréquence des angines et du rhumatisme articulaire aigu fut notée durant une période de 9 mois, la vitesse de sédimentation des hématies étant déterminée durant chaque affection des voies respiratoires supérieures. La fréquence des angines ne dépendit absolument pas du niveau de la réactivité immunologique, mais la corrélation de cette dernière avec la fréquence du rhumatisme articulaire aigu se trouvait être très significative. Tous les douze sujets qui furent atteints de rhumatisme articulaire aigu pendant la période d'observation étaient de bons producteurs d'anticorps incomplet, la plupart d'entre eux étant d'extrêmement bons producteurs. Avec le temps, cependant, le titre de réactivité chez certains individus sembla changer et la netteté des résultats devint moins marquée. On découvrit de plus que les sujets avec des titres élevés avaient une vitesse de sédimentation érythrocytaire substantiellement plus élevée quand ils étaient atteints d'angine que ceux avec des titres bas. La différence était plus évidente pour les chiffres de la vitesse de sédimentation érythrocytaire après deux heures qu'après une heure. Ici aussi la corrélation était plus évidente sitôt après l'évaluation immunologique du sujet, qu'après une periode plus longue. Plusieurs questions concernant les relations entre le réactivité immunologique et la pathogénie du rhumatisme articulaire aigu sont discutées et la possibilité d'une application pratique des résultats obtenus est considérée.
Incidencia del reumatismo poliarticular agudo en relación con la reactividad imunológica

\section{Sumario}

Un grupo homogéneo de 998 sujetos sin signos de 음

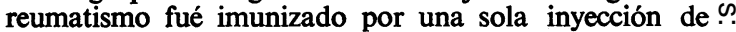
vacune bacteriana Brucella y el anticuerpo incompleto fué $\overrightarrow{\overline{\bar{F}}}$ dosificado en cada sujeto. La frecuencia de las infec- 今ึ ciones de la garganta y del reumatismo poliarticular agudo $\overline{0}$ fué notada durante un período de 9 meses, determinán- 등 dose la velocidad de sedimentación globular durante cada $\overline{\bar{\omega}}$ infección de las vías respiratorias superiores. No hubo relación alguna entre la frecuencia de las infecciones de la $\varrho$ garganta y la intensidad de la reacción imunológica, pero ص encontrose una correlación muy significativa entre ésta y $\circlearrowleft$ la frecuencia del reumatismo poliarticular agudo. Los $\vec{\circ}$ doce sujetos que contrajeron el reumatismo poliarticular agudo durante el período de observación fueron buenos $\vec{\omega}$ productores de anticuerpo incompleto y la mayoría de ellos extremadamente buenos productores. Con el tiempo, sin embargo, la cifra de reactividad en ciertos $\bar{Q}$ sujetos pareció cambiar y los resultados no fueron tan $\vec{\overrightarrow{ }}$ marcados. Se vió, además, que durante una infección de la garganta, los sujetos con cifras altas tuvieron una $\vec{i}$ velocidad de sedimentación considerablemente mayor $\omega$ que los con cifras bajas. Esta diferencia en la velocidad 음 de sedimentación globular fué más marcada a la segunda que a la primera hora. Aquí también la correlación fué más manifesta inmediatamente después de la valoración imunológica del sujeto que después de un período más largo. Se discuten varios problemas respecto a las $\frac{\varsigma}{J}$ relaciones entre le reactividad imunológica y la pato- $\vec{c}$ génesis del reumatismo poliarticular agudo y se considera la posibilidad de una aplicación práctica de los resultadơ . obtenidos. 